\title{
Publication of Investment Treaty Awards: The Qualified Potential of Domestic Access to Information Laws
}

\author{
Filip Balcerzak ${ }^{*}$ and Jarrod Hepburn ${ }^{* *}$
}

DOI: $10.21827 / 5 \mathrm{a} 86 \mathrm{a} 8 \mathrm{~b} 976 \mathrm{e} 29$

\author{
Keywords \\ FREEDOM OF INFORMATION; INVESTMENT ARBITRATION; TRANSPARENCY; POLAND; \\ HUMAN RIGHTS
}

\begin{abstract}
Investment treaties and arbitral rules traditionally impose few legally binding duties on States to release investment treaty awards. Despite this, possibly in light of the growing recognition of a human right of access to public information, recent efforts towards transparency in investment arbitration proceedings have led to significant changes in both legal instruments and State practice. However, many States remain reluctant to commit to transparency obligations, or to comply with transparency obligations where they already exist. This article reviews the utility of one lesserknown tool, domestic freedom of information (FOI) laws, in promoting transparency in the particular context of investment arbitration. The article focuses on the Republic of Poland, a State known to be holding a sizeable number of unpublished investment treaty awards. The Polish experience discussed in this article suggests that, despite the many problems encountered, domestic FOI laws do have the potential, even if qualified, to constitute a factor in the growing trend towards transparency.
\end{abstract}

\section{Introduction}

It is well-recognised that investment treaty disputes involve issues of significant public importance. Recent high-profile disputes have addressed the consistency of State measures ostensibly taken to protect public health, ${ }^{1}$ the environment ${ }^{2}$ or human rights. ${ }^{3}$ The conduct at issue in these disputes is governmental conduct, and the money

\footnotetext{
$\mathrm{PhD}$ candidate, Adam Mickiewicz University in Poznan, Poland. This publication was created with the financial support of the Foundation for Polish Science. This publication is part of the project financed from funds received from the National Science Centre Poland, granted on the basis of decision number DEC-2012/07/N/HS5/01003.

** Lecturer in Law, University of Exeter, United Kingdom.

1 For instance, the tobacco branding measures at issue in Philip Morris Asia Ltd v The Commonwealth of Australia, UNCITRAL, PCA Case No 2012-12, 5 October 2012.

2 For instance, the alleged pollution to areas of the Ecuadorian Amazon rainforest in Chevron Corporation and Texaco Petroleum Company $v$ The Republic of Ecuador, UNCITRAL, PCA Case No 2009-23, 7 November 2014; measures relating to fracking in Lone Pine Resources Inc v Canada, UNCITRAL, ICSID Case No UNCT/15/2.

3 For instance, the issues of indigenous land rights in Bernhard von Pezold v Zimbabwe, ICSID Case No $\mathrm{ARB} / 10 / 15$; and Border Timbers Ltd $v$ Zimbabwe, ICSID Case No ARB/10/25.
} 
used to pay any eventual compensation order is public money. The tribunals constituted under investment treaties to decide such disputes are not only resolving the dispute, but also providing the public good of (quasi-)judicial, reasoned decisions that hold State officials to account for their actions in the public sphere. ${ }^{4}$

Despite this, these tribunals' decisions are not always made available to the public. While some countries - such as the USA and Canada - are known for adopting a proactive stance on disclosure, ${ }^{5}$ others - such as Poland - have proved to be especially reticent in releasing information about pending or concluded investment treaty claims. Where the parties to a dispute are reluctant to release information, observers who favour transparency must therefore consider alternative means by which information can be obtained.

Section 1 of this article reviews possible obligations of disclosure under investment treaties, arbitral rules or certain domestic laws on enforcement of arbitral awards. Apart from specific and more recent developments, Section 1 finds few binding duties on respondent States (or claimants) to release investment treaty awards.

Section 2, therefore, turns to another potential source of obligations on States to release awards - namely, human rights law. As Section 2 discusses, both international and regional human rights instruments and case-law now recognise a human right of access to information. Domestic governmental authorities, as well as domestic judges, should therefore pay close attention to their human rights obligations when ruling on requests for information, including access to investment treaty awards held by the State. In particular, Section 2 suggests that any exceptions or limitations placed on a general right of access must be interpreted as narrowly as possible, to satisfy the demands of human rights obligations binding on most States in the world.

One means adopted by many States to fulfil this human right of access to information has been to pass domestic laws on freedom of information (the FOI laws). In the absence of a more specific duty of disclosure as shown in Section 1, the article considers in Section 3 the utility of these laws for parties seeking publication of awards. In particular, Section 3 focuses on the Republic of Poland, as it is currently known to be holding a sizeable number of unpublished investment treaty awards. Section 3 discusses a number of recent requests made to Polish authorities for the release of several investment treaty awards, together with efforts in domestic courts to seek to hold the Polish State to its commitments under the 2001 Law on Access to Public Information. ${ }^{6}$

As Section 3 makes clear, States have sometimes denied requests for access to investment treaty awards relying on various exceptions in domestic FOI laws. In light of the human rights obligations discussed in Section 2, the article concludes that reliance on these exceptions - at least in the manner demonstrated by the Polish executive, under examination in Section 3 - has not been confirmed on review by the judiciary. Efforts undertaken under the local FOI law have, to a certain degree, been

4 Rogers, C, "International Arbitration's Public Realm" in Rovine, A, ed, Contemporary Issues in International Arbitration and Mediation: The Fordham Papers (Martinus Nijhoff Publishers, Leiden, 2011).

5 See, eg., the publicly-available materials posted on the US State Department website, at $<$ state.gov/s/1/c3439.htm> (accessed 03 April 2015).

6 Act of 6 September, 2001 on Access to Public Information, Poland (2001), Journal of Laws No 112 pos 1198 as amended (the FOI Act). The English translation of the Act available at $<$ unpan1.un.org/intradoc/groups/public/documents/unpan/unpan034035.pdf> (accessed 20 April 2015 ) is used for the purposes of quotations in this article. 
successful. The experience discussed in this article suggests that, despite the many problems encountered, domestic FOI laws do have the potential, even if qualified, to constitute a factor in the growing trend towards transparency.

\section{Traditional Disclosure Obligations on Parties to an Investment Treaty Dispute}

Although arbitration is traditionally a confidential enterprise, it is clear that many investment treaty awards are voluntarily released by one or both parties to a dispute. In the absence of a voluntary disclosure, what provisions might govern the release of awards? This Section reviews three possibilities: the provisions of investment treaties themselves, the provisions of the arbitral rules that govern the dispute and the provisions of domestic law that govern arbitral award enforcement proceedings.

\section{II.1. Obligations of Disclosure under Investment Treaties}

Some investment treaties explicitly provide that final awards and other relevant documents will be made available to the public as a matter of course. For instance, Article 10.21 of the Dominican Republic-Central America Free Trade Agreement (DRCAFTA) requires a respondent State in a claim under DR-CAFTA to publish the notice of arbitration, all pleadings from both parties, and all orders, awards and decisions of the tribunal. Exceptions are permitted only for 'protected information' identified by either party, presumably intended to allow redactions of confidential commercial information. ${ }^{7}$ Notably, Article 10.21(5) provides that nothing in the transparency provisions of Article 10.21 'requires a respondent to withhold from the public information required to be disclosed by its laws'. In other words, Article 10.21(5) specifies that domestic FOI laws, amongst other relevant domestic laws, are to take precedence over any potential obligation in Article 10.21 of DR-CAFTA to maintain confidentiality over certain information. However, even DR-CAFTA considered by many to be the high-water mark of transparency in investment treatymaking to date - contains an exception to disclosure if this would be 'contrary to the public interest'. ${ }^{8}$ Although the claims brought so far under DR-CAFTA have been conducted in a highly transparent fashion (even including live online broadcasts of merits hearings), ${ }^{9}$ the 'public interest' exception in Article 21.5 still remains theoretically available to thwart an interested party's access to final awards in DRCAFTA cases.

A precursor to DR-CAFTA, the North American Free Trade Agreement (NAFTA), sets out a differentiated regime for publication of awards depending on the State party to a dispute. Under Annex 1137.4, the United States and Canada have agreed that an investor (or the State itself) may publish a NAFTA award, while Mexico provides

Article 10.21(4), The Dominican Republic-Central America-United States FTA (FTA) (DR-CAFTA) (2004). The Article specifies that the tribunal shall decide any objections relating to the designation of information designated as 'protected'. However, the Article does not require any statement of reasons from a party seeking to designate certain information as protected, nor does it specify any grounds on which the tribunal is to determine whether the designation was appropriate or not.

Article 21.5, The Dominican Republic-Central America-United States FTA (2004).

9 Railroad Development Corporation v Guatemala, ICSID Case No ARB/07/23, Award, 29 June 2012, para 23. 
only that the applicable arbitration rules are to govern the matter. ${ }^{10}$ Since Mexico is not a party to the ICSID Convention, ${ }^{11}$ this provision means in practice that either the UNCITRAL Arbitration Rules ${ }^{12}$ or ICSID's Additional Facility Rules ${ }^{13}$ (discussed further below) will determine whether NAFTA awards against Mexico may be published by one disputing party without specific consent of the other party.

Meanwhile, the large majority of investment treaties - particularly older ones - are silent on the question of the parties' or the tribunal's duty or power to publish awards and other documents. In disputes under these treaties, the issue may be regulated by the choice of arbitral rules agreed on by the parties to govern the arbitration.

\section{II.2. Obligations of disclosure under arbitral rules}

Indeed, the major sets of arbitral rules commonly used in investment arbitration contain various provisions relating to (non-)disclosure of awards and other documents such as jurisdictional decisions or parties' pleadings.

Article 48(5) of the ICSID Convention provides that ' $[\mathrm{t}]$ he Centre shall not publish the award without the consent of the parties.' This provision captures the underlying ethos of arbitration as a private mechanism of dispute resolution and appears to commit ICSID to a position of confidentiality, as is the norm in arbitration proceedings more generally. States, of course, may favour confidentiality in investment treaty disputes out of a perception that the secrecy of arbitration will avoid embarrassment and jeopardy to the State's investment climate. Similarly, investor claimants may also favour confidentiality, out of a desire to protect their commercial information, to avoid tarnishing their public reputation or, perhaps, to preserve an ongoing relationship with the host State.

However, as a tool of confidentiality, Article 48(5) is limited in two major ways. First, it is clear that the provision applies only to ICSID itself. ${ }^{14}$ Article 48(5) does not prevent either or both of the disputing parties themselves to release the tribunal's award. ${ }^{15}$ Many ICSID awards are, in fact, voluntarily released by one party (often the successful party). Second, according to the view expressed by Schreuer, strictly speaking Article 48(5) applies only to 'the award', a term which does not include preliminary rulings of ICSID tribunals such as jurisdictional decisions or procedural orders. ${ }^{16}$ In some cases where merits and quantum are bifurcated, the final award may consider only issues of calculating damages, the tribunal having already ruled on jurisdiction and merits in a previous 'decision'. In these instances, following the above-mentioned point of view, Article 48(5) would not technically prevent ICSID from unilaterally publishing the jurisdictional or merits rulings while still keeping the final 'award' confidential. However, in practice, ICSID has not followed this 'illogical'

10 Like DR-CAFTA, Article 21.5, North American FTA (NAFTA) also contains a general exception to disclosure in Article 2105. However, the exception is more narrowly framed, covering only law enforcement, personal privacy and financial information, and not including 'public interest'.

11 Convention on the Settlement of Investment Disputes between States and Nationals of Other States (1965) 4 ILM 524 (ICSID Convention).

12 United Nations Commission on International Trade Law (UNCITRAL), UNCITRAL Arbitration Rules (as revised in 2010) (UNCITRAL Arbitration Rules).

13 International Centre for Settlement of Investment Disputes (ICSID), Additional Facility Rules (2003) ICSID/11/Rev 1 (ICSID's Additional Facility Rules).

14 Schreuer, C, The ICSID Convention: A Commentary (2nd edn, Cambridge University Press, 2009 ), 835.

15 World Duty Free Company Ltd v Kenya, ICSID Case No ARB/00/7, Award, 4 October 2006, para 16.

16 Schreuer, supra nt 14, 837. 
approach ${ }^{17}$ and has refrained from publishing any document relevant to an arbitration without the parties' consent.

Since April 2006, following an amendment to the ICSID Arbitration Rules, ICSID is required to 'promptly include in its publications excerpts of the legal reasoning of the Tribunal' in every case. ${ }^{18}$ Although ICSID 'has yet to publish excerpts of the reasoning of awards in a systematic manner', ${ }^{19}$ it appears that the ICSID Secretariat takes the pragmatic approach of focusing its efforts to collate award excerpts on those awards which have not otherwise been made public. ${ }^{20}$ For instance, in January 2013, ICSID released excerpts of a 2011 award against the Central African Republic, after neither disputing party took any steps towards the release of the award. ${ }^{21}$ In that case, these excerpts included substantially the entire award, apart from extensive discussion of the facts and each party's pleadings ${ }^{22}$ meaning that publication of excerpts under Arbitration Rule 48(4) may come close to fulfilling the objectives of those who favour full transparency in the publication of awards.

Under Article 32(5) of the UNCITRAL Arbitration Rules of 1976, an arbitral award 'may be made public only with the consent of both parties'. On the face of this text, it is unclear whether the injunction on publication applies only to the tribunal, as in the ICSID Convention, or also to the parties themselves. However, the context of Article 32 may suggest that it places obligations only on the tribunal itself, leaving the parties free to determine unilaterally whether one or both may release an award. ${ }^{23}$

The revised UNCITRAL Arbitration Rules, released in 2010, include additional language in Article 32(5), now renumbered as Article 34(5). The new provision explicitly takes account of situations where one party has a legal duty to disclose an arbitral award, confirming that a domestic law duty to release an award will override any possible duty of confidentiality found in the UNCITRAL Arbitration Rules themselves. ${ }^{24}$ The LCIA Rules (less commonly used in investment arbitration) contain a similar provision. ${ }^{25}$ The SCC Rules ${ }^{26}$ meanwhile, direct the Stockholm Chamber of Commerce (SCC) and the tribunal itself to maintain the confidentiality of the award (in Article 46), but do not expressly prohibit the parties from disclosing information.

However, for disputes utilising the UNCITRAL Arbitration Rules and arising out of investment treaties concluded on or after 1 April 2014, the new UNCITRAL Rules on Transparency will apply. ${ }^{27}$ These rules impose an extensive transparency regime,

17 Ibid.

18 Rule 48(4), ICSID Rules of Procedure for Arbitration Proceedings (2006) (ICSID Arbitration Rules).

19 Schreuer, supra nt 14, 835.

20 ICSID, Annual Report 2013 (ICSID, 2013) 41.

21 Meerapfel Söhne AGv Central African Republic, ICSID Case No ARB/07/10, Arbitral Award, 12 May 2011 (Meerapfel case).

22 However, it might be added that, in the Meerapfel case, ICSID also redacted the final amount ordered against the respondent State, a potentially significant piece of information.

23 Except for the second sentence of Article 32(2), all the other provisions of Article 32 are clearly directed to the tribunal itself, and not the parties.

24 Article 34(5) reads that '[a]n award may be made public with the consent of all parties or where and to the extent disclosure is required of a party by legal duty, to protect or pursue a legal right or in relation to legal proceedings before a court or other competent authority'.

25 Article 30.1, London Court of International Arbitration (LCIA), LCIA Arbitration Rules, effective 1 October 2014 (LCIA Rules).

26 Stockholm Chamber of Commerce (SCC), Arbitration Rules (2010) in force as of 1 January 2010 (SCC Rules).

27 UNCITRAL, UNCITRAL Rules on Transparency in Treaty-based Investor-State Arbitration, effective 1 April 2014 (UNCITRAL Rules on Transparency). 
including publication of substantive pleadings, final awards and other documents associated with arbitration proceedings. ${ }^{28}$ Furthermore, in December 2014, the UN General Assembly adopted a multilateral convention, the UN Convention on Transparency in Treaty-based Investor-State Arbitration (UN Transparency Convention), ${ }^{29}$ open for signature from 17 March 2015. Under this Convention, a signatory State agrees to apply the UNCITRAL Transparency Rules to any dispute arising under an investment treaty of that State which came into force before 1 April 2014 (unless that treaty is included in the State's opt-out list attached to the Convention).

These developments at UNCITRAL are particularly significant because, as between the two major arbitral fora that hear investment treaty disputes, to date it has been UNCITRAL awards that have remained hidden to a much greater degree than awards rendered at ICSID. ${ }^{30}$ Certainly, the large majority of existing investment treaties were signed before 1 April 2014, meaning that respondent State consent will be required (either given specifically in a dispute or in advance via accession to the new UN Transparency Convention) before the more onerous disclosure provisions will operate. However, the developments add a new source of pressure on host States to agree to publication of awards, and they confirm an unmistakeable trend in favour of publication.

\section{II.3. Obligations of Disclosure During Enforcement Proceedings}

As noted by Schreuer, ${ }^{31}$ another occasional means by which investment treaty awards enter the public domain is when the successful party seeks enforcement of the award via domestic courts in a jurisdiction where the losing party holds assets. ${ }^{32}$ In order to obtain recognition and enforcement of an arbitral award in most jurisdictions, the award itself (and sometimes a translation into the language of the relevant court) must be entered into evidence in the court proceedings. Once this has occurred, the award can become a public document, like any other evidence filed in domestic judicial proceedings. However, not all jurisdictions would permit public consultation of court case files, hindering access to evidence submitted in the course of the court proceedings to the parties and other participants in the proceedings. ${ }^{33}$ Furthermore, even where public access to files is possible, there is no simple or systematic means by which to locate and become informed of such domestic enforcement proceedings, limiting the utility of this mechanism of award disclosure.

28 Article 3, UNCITRAL Rules on Transparency.

29 United Nations, Convention on Transparency in Treaty-based Investor-State Arbitration, New York, 10 December 2014, A/RES/69/116 (UN Transparency Convention).

30 See, eg., discussion of the Polish cases below. This is largely because the existence of a dispute, at least, is disclosed when ICSID registers a case on its public website, while even the existence of disputes under the current UNCITRAL rules - let alone any documents from the case such as the final award - may never be made public.

31 Schreuer, supra nt 14, 837.

32 Usually this will be the investor seeking to enforce an award against State assets held in a foreign jurisdiction. However, States may also attempt to enforce tribunal orders for costs against an unsuccessful investor.

33 In Poland, for instance, the relevant court rules prevent public access to the case file. According to Article 9, Section 2, Polish Code of Civil Procedure, cases are publicly heard, unless a specific regulation provides otherwise. However, only parties and other participants in the proceedings have the right to consult the case file and receive copies of documents. 


\section{II.4. Conclusions}

Overall, whether through voluntary publication by (one of) the parties, mandated publication under the terms of a more recent investment treaty or set of arbitral rules, publication of substantive excerpts by ICSID or disclosure of awards during enforcement proceedings, the substance of many known investment treaty disputes does, at present, find its way into the public domain. ${ }^{34}$

\section{The Human Right of Access to Information}

Apart from investment treaties and arbitral rules themselves, one other major source of obligations relating to disclosure of information is found in human rights law. The major human right underpinning the analysis in this Section is the right to freedom of expression. This right is routinely recognised as one of the most fundamental human rights. In its typical manifestation, the right to freedom of expression protects positive acts done by the beneficiary of the right, such as publishing a text, making statements to the media or publicly displaying artistic works or symbols. ${ }^{35}$ However, it is wellrecognised that the right to freedom of expression extends beyond the positive dissemination of information and ideas to others, also entailing a right to receive information and ideas from others. Indeed, Article 19 of the Universal Declaration of Human Rights (UDHR) ${ }^{36}$ recognises the 'right to freedom of opinion and expression', and explicitly provides that 'this right includes freedom ... to seek [and] receive ... information and ideas through any media and regardless of frontiers'.

This right of access to State-held information has been increasingly recognised in both international and regional human rights instruments and case-law.

\section{III.1. International Human Rights Law}

In 1946, the early days of the United Nations, the General Assembly agreed that freedom of information was 'a fundamental human right', 'the touchstone of all the freedoms to which the United Nations is consecrated' and 'an essential factor in any serious effort to promote the peace and progress of the world' ${ }^{37}$ More recently, the UN Special Rapporteur on the Promotion and Protection of the Right to Freedom of Expression stated in 1995 that '[a]ccess to information is basic to the democratic way

34 Cf, Hafner-Burton, E, Steinert-Threlkeld, Z and Victor, D, "Transparency of Investor-State Arbitration", $\quad 30 \quad$ April 2014, <irps.ucsd.edu/ehafner/pdfs/Transparency_in_Arbitration_2014.pdf> (accessed 03 April 2015), 1: who assert that $40 \%$ of final awards in ICSID cases have remained secret over the institution's lifetime.

35 Harris, D, O'Boyle, M, Bates, E and Buckley, C, Law of the European Convention on Human Rights (2nd ed, Oxford University Press, Oxford, 2009), 443-445.

36 UN General Assembly, Universal Declaration of Human Rights, 10 December 1948, 217 A (III) (UDHR),

37 United Nations General Assembly, Calling of an International Conference on Freedom of Information, 14 December 1946, (65th Plenary Meeting) A/RES/59 (I) at <un.org/en/ga/search/view_doc.asp?symbol=A/RES/59\%28I\%29> (accessed 20 April 2015). 
of life. The tendency to withhold information from the people at large is therefore to be strongly checked. ${ }^{38}$

The International Covenant on Civil and Political Rights (ICCPR) ${ }^{39}$ also protects freedom of expression in its Article 19. Like the UDHR, the ICCPR confirms that the right to freedom of expression entails not only the right to hold opinions, express ideas and impart information, but also the 'freedom to seek [and] receive information and ideas of all kinds, regardless of frontiers'. ${ }^{40}$ Article 19 of the ICCPR has been the subject of a General Comment issued in 2011 by the UN's Human Rights Committee, the treaty body that monitors compliance with the ICCPR by its 168 States parties. ${ }^{41}$ General Comments are taken to constitute authoritative interpretations of the meaning and scope of the ICCPR rights. ${ }^{42}$ In its General Comment No. 34, the Human Rights Committee acknowledged that Article 19(2) 'embraces a right of access to information held by public bodies'. ${ }^{43}$ Moreover, ' $[t]$ o give effect to the right of access to information, States parties should proactively put in the public domain Government information of public interest. States parties should make every effort to ensure easy, prompt, effective and practical access to such information'. ${ }^{44}$ For information that is not proactively made available, 'States parties should also enact the necessary procedures, whereby one may gain access to information, such as by means of freedom of information legislation' including provisions for reasons and appeals if necessary. ${ }^{45}$

Both General Comment No 34 and Article 19 accept that restrictions on free expression (including access to information) will sometimes be justified. However, Article 19(3) specifies that any restrictions must be 'provided by law' and must be 'necessary ... for respect of the rights or reputations of others' or 'for the protection of national security or of public order (ordre public)'. ${ }^{46}$ The General Comment offers guidance for States parties seeking to implement restrictions. Where restrictions are to be imposed, they 'may not put in jeopardy the right itself', nor may States reverse the 'relation between right and restriction', ${ }^{47}$ indicating that restrictions must be narrowly tailored to ensure that release of information remains the default position.

Even the potentially wide-ranging exception for 'national security' must be constrained under the approach adopted in the General Comment. 'Extreme care must be taken' to ensure that provisions relating to national security 'are crafted and applied in a manner that conforms to the strict requirements of paragraph 3 ' ${ }^{48}$ Such an exception must not be used, the Committee warns, 'to suppress or withhold from the public information of legitimate public interest that does not harm national security'. ${ }^{49}$

38 United Nations Economic and Social Council, Report of the Special Rapporteur, Mr Abid Hussain, pursuant to Commission on Human Rights Resolution 1993/45, UN Doc E/CN4/1995/32, para 35.

39 United Nations General Assembly, International Covenant on Civil and Political Rights (1966) 999 UNTS 171 (ICCPR).

40 Article 19(2), ICCPR.

41 See the ratification information at <indicators.ohchr.org/> (accessed 20 April 2015).

42 Crawford, J, Brownlie's Principles of Public International Law (8th ed, Oxford University Press, 2012), 640.

43 Human Rights Committee, General Comment No 34, UN Doc CCPR/C/GC/34, 12 September 2011, para 18 (GC34).

44 Id, para 19.

45 Ibid.

46 Article 19(3) also permits restrictions to protect public order, public health or morals.

47 GC34, para 21.

$48 I d$, para 30.

49 Ibid. 
Furthermore, the General Comment reminds States that any restrictions on the public's ability to seek and receive information must be necessary for a legitimate purpose. ${ }^{50}$ In a slightly different context, the Committee discusses one potential example of an illegitimate purpose (namely, protecting public figures or institutions from criticism), and expresses concern over laws restricting this activity (such as lèsemajesté laws). ${ }^{51}$ In light of the extensive public interest in investment treaty disputes, these comments from the Human Rights Committee would suggest that a State's refusal of access to investment treaty awards on grounds that to do so would embarrass the government (even if such grounds are not explicitly stated by the authorities) would not conform to the international understanding of the obligations in Article 19 of the ICCPR, binding on 168 States.

The General Comment also reminds States that ' $[\mathrm{t}]$ he obligation to respect freedoms of opinion and expression is binding on ... [a]ll branches of the State (executive, legislative and judicial)' ${ }^{52}$ Furthermore, States parties 'are required to ensure that the rights contained in Article 19 of the Covenant are given effect to in the domestic law of the State'. Indeed, according to one non-governmental organisation (NGO) that monitors FOI laws, 100 countries had adopted nation-wide domestic FOI legislation as of September $2014 .{ }^{53}$ Demonstrating a clear contemporary trend towards transparency, almost all of these countries adopted their FOI laws in the last twenty years (with some remarkable outliers like Sweden, whose FOI law is dated to 1766). ${ }^{54}$

\section{III.2. Inter-American Human Rights Law}

Regional human rights instruments also contain instantiations of the right to freedom of expression, and, like the international instruments just reviewed, these regional instruments have also been construed to cover a right of access to information held by the government. In particular, the American Convention on Human Rights ${ }^{55}$ contains wording in its Article 13 similar to the ICCPR's Article 19, providing that 'this right [to freedom of expression] includes freedom to seek [and] receive ... information and ideas of all kinds, regardless of frontiers'.

Article 13's connection to freedom of information was examined in the 2006 Claude Reyes et al $v$ Chile case before the Inter-American Court of Human Rights. This case related to a proposed large-scale sawmill and timber processing plant located in Tierra del Fuego on Chile's southernmost tip. In 1991, the State's Foreign Investment Committee approved an investment of USD 180 million from US-based investors to construct the sawmill. ${ }^{56}$ The proposed project, in an area of high environmental value,

$50 \quad I d$, para 33.

Id, para 38.

Id, para 7.

53 The Global Network of Freedom of Information Advocates, freedominfo.org, FOI Countries by Date (September 2014) at <freedominfo.org/regions/global/foi-regimes/> (accessed 28 March 2015).

54 University College London Constitution Unit, Swedish International Focus (Freedom of the Press Act 1766), 30 September 2011 at <ucl.ac.uk/constitution-unit/research/foi/countries/sweden> (accessed 20 April 2015).

55 Organization of American States (OAS), American Convention on Human Rights, "Pact of San Jose", Costa Rica, 22 November 1969.

56 Inter-American Court of Human Rights, Claude Reyes et al v Chile, Judgment of 19 September 2006, para $57(6)$. 
attracted significant public attention from observers concerned about the potential adverse effects of logging in the area. ${ }^{57}$

In 1998, while the project was still in its early stages, several individuals, members of a Chilean environmental NGO, submitted a request to the Foreign Investment Committee seeking information on the identity of the investors involved and their environmental track records, as well as details of various other elements of the project. The Committee responded with some of the information requested, but denied other parts, and did not provide reasons for their decision. ${ }^{58}$ The individuals appealed the decision to Chile's Supreme Court, but failed to obtain the information sought. They then took their case to the Inter-American Commission on Human Rights, which itself referred the case to the Inter-American Court after Chile failed to comply with the Commission's finding of a breach.

In a September 2006 ruling, the Court held that Article 13 of the American Convention 'protects the right of all individuals to request access to State-held information', and entails a 'positive obligation of the State to provide it', except where legitimate restrictions apply. ${ }^{59}$ The Court referred to widespread consensus amongst American ${ }^{60}$ and European ${ }^{61}$ States that access to government information was essential for democratic participation, and it noted the trend towards establishment of domestic FOI laws. ${ }^{62}$ In particular, the Court said,

[d]emocratic control by society, through public opinion, fosters transparency in State activities and promotes the accountability of State officials in relation to their public activities. Hence, for the individual to be able to exercise democratic control, the State must guarantee access to the information of public interest that it holds. By permitting the exercise of this democratic control, the State encourages greater participation by the individual in the interests of society. ${ }^{63}$

The Court ultimately held that the Foreign Investment Committee's failure to provide the requested information relating to the foreign investment project, without any reasoned explanation for why restrictions on the right to access information might have applied, constituted a violation of Article 13 of the American Convention. ${ }^{64}$

Although the Claude Reyes case was heard in a human rights forum, the investment project underlying the case could easily have become the subject of an investment treaty claim against Chile if, for instance, faced with further pressure from local environmental groups, Chile had taken any steps to limit the scope of the logging and sawmill operations after having approved the investment. Any award of a tribunal in a hypothetical Bilateral Investment Treaty (BIT) claim against Chile would be likely to carry great public interest, weighing heavily in favour of its public disclosure - just as

$57 I d$, paras 57(7), 66.

58 During proceedings before the Inter-American human rights bodies, the Executive Vice President of the Committee testified that he had refused certain requested information partly because it would have disclosed confidential financial information of the relevant investors, and partly because the Committee did not have the relevant information: $I d$, para 57(20).

$59 \quad I d$, para 77.

$60 \quad I d$, paras 78-80.

${ }^{61} I d$, para 81 .

${ }_{62} I d$, para 82.

$63 \quad I d$, para 87.

$64 I d$, para 103. 
the Inter-American Court ordered in relation to the information initially sought by the Claude Reyes petitioners.

\section{III.3. European Human Rights Law}

Alongside these developments in the inter-American human rights system, the European Court of Human Rights has also relatively recently taken strides towards recognising a general right to access State-held information of public interest. ${ }^{65}$ Article 10 of the European Convention on Human Rights (ECHR) ${ }^{66}$ includes a right to expression framed, once again, in very similar terms to Article 13 of the American Convention and Article 19 of the ICCPR. Article 10 of the ECHR provides that ' $[\mathrm{e}]$ veryone has the right to freedom of expression. This right shall include freedom to ... receive and impart information and ideas without interference by public authority and regardless of frontiers.'

In its ruling of April 2009 in Társaság a Szabadságjogokért v Hungary, the European Court of Human Rights addressed the question of whether the claimant, a Hungarian NGO, had been the victim of a violation of Article 10 ECHR when the Hungarian Constitutional Court had denied access to a complaint that had been filed with it by a member of the Hungarian Parliament. The Hungarian Constitutional Court had contended that the complaint could not be made available to outsiders, such as the NGO, without the consent of its author, the Hungarian Parliamentarian. ${ }^{67}$ Following unsuccessful efforts to gain access via domestic court proceedings, the NGO filed its case at the European Court of Human Rights in Strasbourg.

The Court held that there had been an interference with Társaság's rights, in that the claimant had been prevented from both receiving and, given that it planned to make the constitutional complaint more widely available, imparting information. The Court then considered whether this interference was justified, as permitted under Article 10(2) of the ECHR, by being 'necessary in a democratic society'. In this context, the Court observed that it had 'recently advanced ... towards the recognition of a right of access to [State-held] information'. The Court added that the actual information sought by the claimant was 'ready and available' to the relevant State authority (the Constitutional Court), and 'did not require the collection of any data by the Government'. ${ }^{68}$ A violation of Article 10 was therefore upheld.

Although the Court's ruling was clearly influenced by the fact that the claimant was to be 'characterised, like the press, as a social 'watchdog'69 rather than an ordinary citizen, the case certainly demonstrates that refusals of access to information particularly where the information is 'ready and available' to the government (such as, perhaps, an investment treaty award) - can violate European human rights law. This approach was confirmed more recently in Österreichische Vereinigung zur Erhaltung, Stärkung und Schaffung $v$ Austria. ${ }^{70}$ There, the Court held that 'a complete refusal to give

65 See Hins, W and Voorhoof, D, "Access to State-Held Information as a Fundamental Right under the European Convention on Human Rights", 3 European Constitutional Law Review (2007) 114.

66 Council of Europe, European Convention for the Protection of Human Rights and Fundamental Freedoms, as amended by Protocols Nos. 11 and 14 (1950) ETS 5 (ECHR).

67 European Court of Human Rights (ECtHR), Társaság a Szabadságjogokért v Hungary, 37374/05, 14 April 2009, para 10 (Társaság case).

${ }_{68} I d$, para 36. In this context, see also section 3.3 .2 below.

${ }^{69} I d$, para 27.

70 ECtHR, Österreichische Vereinigung zur Erhaltung, Stärkung und Schaffung v Austria, 39534/07, 28 November 2013. 
[the applicant] access to any of [the Tyrol Real Property Transactions Commission's] decisions was disproportionate', particularly given that the Commission was a public authority deciding disputes over civil rights of considerable public interest. ${ }^{71}$ Similarly, in another recent case, a decision by the Serbian Intelligence Agency to deny certain information to an NGO, who had applied for the information under that country's FOI law, was held by the European Court of Human Rights to violate Article 10 of the ECHR, partly due to the 'unpersuasive' reasons offered by the Intelligence Agency for its refusal. ${ }^{72}$

\section{Access to Investment Treaty Awards via Domestic FOI Law: a Polish Case-Study}

\section{IV.1. Introductory Remarks}

This section considers the potential for domestic freedom of information law to play a role in gaining access to investment treaty cases. Drawing on recent experiences, this section focuses on Poland, a State which has kept a number of investment treaty awards unpublished for many years.

At the outset, as noted in Section 1, there is no necessary obligation on respondent States to make public even the fact of a pending dispute, particularly where those disputes are heard in arbitral fora outside ICSID. Indeed, some countries may be involved in ongoing disputes, the details of which are completely hidden from public view. In these situations, it may be difficult to use domestic FOI laws to obtain specific documents, since the existence of those documents will be unknown to the applicant. However, when the existence (at least) of the dispute is known, FOI laws may prove useful. Using Poland as an example, attempts of this kind are described below.

\section{IV.2. The Right to Public Information in the Polish Legal System}

Under Article 61 of the Constitution of Poland, 'a citizen shall have the right to obtain information on the activities of organs of public authority as well as persons discharging public functions.'

As with other fundamental rights guaranteed in the Polish Constitution, this right to public information is not absolute. Limitations can apply in order to "protect freedoms and rights of other persons and economic subjects, public order, security or important economic interests of the State'. ${ }^{73}$ However, under Article 31.3 of the Constitution,

71 Id, paras $46-47$

72 ECtHR, Youth Initiative for Human Rights $v$ Serbia, 48135/06, 25 June 2013, para 25. See also comments in ECtHR, Gillberg $v$ Sweden, 41723/06, 3 April 2012, para 93, to the effect that scientific researchers held 'rights under Article $10 \ldots$ to receive information in the form of access to the public documents concerned'.

73 Article 61, Constitution of the Republic of Poland, Poland (1997) reads as follows:

1. A citizen shall have the right to obtain information on the activities of organs of public authority as well as persons discharging public functions. Such right shall also include receipt of information on the activities of self-governing economic or professional organs and other persons or organizational units relating to the field in which they perform the duties of public authorities and manage communal assets or property of the State Treasury. 
any limitation upon the exercise of constitutional freedoms and rights may be imposed only by statute, and only when necessary in a democratic State for the protection of its security or public order, or to protect the natural environment, health or public morals, or the freedoms and rights of other persons. Such limitations shall not violate the essence of freedoms and rights.

This constitutional right to public information has been implemented in a 2001 statute, the Act on Access to Public Information (the FOI Act or the Act). ${ }^{74}$ The FOI Act broadens the scope of the constitutional right and covers all persons, not only Polish citizens. ${ }^{75}$ In Article 1.1, it provides that "each information on public matters constitutes public information in the understanding of the Act and is subject to being made available on the basis of principles and under the provisions defined in this Act.' In Article 1.2, the Act provides that ' $\mathrm{t}]$ he provisions of the Act shall not breach the provisions of other acts defining different principles and the mode of access to the information being public information.'

The Act contains several provisions that exempt specific types of information from disclosure by Polish authorities. Thus, access to public information can be refused 'to the extent and on the principles defined in the provisions on the protection of confidential information and on the protection of other secrets being statutorily protected'. ${ }^{76}$ Moreover, 'the right to public information is subject to limitation in relation to privacy of a natural person or the secret of an entrepreneur. ${ }^{, 77}$

Upon receipt of a request for access to public information, Polish authorities may decide, as a matter of fact, to provide the applicant with the requested information. This course of action does not require the authority to issue any formal administrative decision under Polish law. However, if for any reason the request is denied, the authority is obliged to render an administrative decision. ${ }^{78}$ In this situation, the applicant is entitled to appeal the administrative decision to a superior authority. ${ }^{79}$ If the initial request was already addressed to the highest relevant authority, such as the

2. The right to obtain information shall ensure access to documents and entry to sittings of collective organs of public authority formed by universal elections, with the opportunity to make sound and visual recordings.

3. Limitations upon the rights referred to in paras. 1 and 2 above, may be imposed by statute solely to protect freedoms and rights of other persons and economic subjects, public order, security or important economic interests of the State.

4. The procedure for the provision of information, referred to in paras. 1 and 2 above shall be specified by statute, and regarding the Sejm and the Senate by their rules of procedure.'

74 The FOI Act.

75 Article 2, the FOI Act: 'Each person is entitled, with the stipulation of Article 5, to the right of access to public information ...'.

76 Article 5.1, the FOI Act.

77 Article 5.2, the FOI Act. Although:

The limitation does not relate to the information on persons performing public functions, being connected with performing these functions, including the conditions of entrusting and performing these functions and in the event when a natural person or entrepreneur resigns from the right to which he was entitled to.

78 Article 16.1 of the FOI Act: 'The refusal to make the public information available and discontinuation of proceedings to make the information available in the case defined in Article 14, it. 2 by the body of public authority takes place by means of a decision'.

79 Article 127 Section 2, Polish Code of Administrative Procedure in relation to Article 16.2, the FOI Act. 
responsible Minister (as would typically occur in the context of requests for access to investor-State arbitral awards), the possibility of appeal is replaced by a motion for reconsideration of the decision by the same authority. ${ }^{80}$ The FOI Act obliges the authority to render a decision on the appeal (or on the reconsideration) within 14 days. ${ }^{81}$ If the competent authorities continue to deny access to the public information, the applicant is entitled to present a claim to the administrative court.

\section{IV.3. First Attempts at Relying on the FOI Act to Access an Investor-State Arbitral Award: Servierv Poland ${ }^{82}$}

The first publicly-known attempts to use the FOI Act to obtain copies of one of Poland's many unpublished investor-State arbitral awards commenced in 2012 and targeted the February 2012 award of an UNCITRAL-rules tribunal in Servier $v$ Poland. The Servier case was brought under the Poland-France BIT and related to pharmaceutical authorisations, implicating both Poland's Ministry of Health and its State Treasury Solicitors' Office (the STSO). The STSO by law represents the Polish State in arbitral proceedings (although it is common that external counsel is also appointed in investment treaty cases). ${ }^{83}$ Separate motions were filed under the FOI Act to the STSO and to the Ministry of Health. Due to the unprecedented nature of these efforts, various actors were involved in preparing the filings. ${ }^{84}$

80 Poland did not designate an entity responsible for conducting investor-State arbitrations. In general, the authority involved in an alleged breach of a Bilateral Investment Treaty (BIT) will represent the State in the arbitral proceedings (together with the State Treasury Solicitors' Office (STSO) and, typically, external counsel). Therefore, the Minister responsible for the sector related to a dispute will be the responsible authority and, thus, addressee of a request under the FOI Act. For avoidance of doubt and for linguistic ease, in the text of this article, the authors refer to the various Ministries, rather than the individual Ministers. However, formally speaking, the Ministers themselves are the authorities that issued the relevant decisions, and that are parties to proceedings before the administrative courts if complaints against such decisions are filed.

81 Article 16.2, the FOI Act.

82 Les Laboratoires Servier, SAA, Biofarma, SAS, Arts et Techniques du Progres SAS v Republic of Poland, UNCITRAL (Servier $v$ Poland) or (Servier).

83 The STSO was created by the Act of 8 July, 2005 on the State Treasury Solicitors' Office, Journal of Laws No 169 pos 1417 as amended, which also regulates the scope of the STSO's responsibilities.

84 Investment Arbitration Reporter; Krzysztof Izdebski from the 'Citizen Network - Watchdog Poland', who undertook the majority of steps described in the present section with respect to the Servier $v$ Poland case; the Center for International Environmental Law, which submitted two amicus curiae briefs, one of which is available at <italaw.com/sites/default/files/casedocuments/italaw1563.pdf> (accessed 10 May 2015); and Professor Andrew Newcombe, who provided an affidavit (dated 26 March 2013) as to the number of published documents relevant in the context of investor-State arbitration, with special focus on the Member States of the European Union. 


\section{IV.3.1. The STSO Proceedings}

The motion filed with the STSO in May $2012^{85}$ saw very little initial success, with the STSO replying simply that (in its view) it was not an authority covered by the FOI Act, and therefore was not obliged to release any public information. The applicant filed a motion for reconsideration, but the STSO maintained its position. ${ }^{86}$

A complaint to the relevant Polish administrative court was then filed. In its submissions to the court, the STSO again contended that it was not bound by the FOI Act. Interestingly, though, the STSO further argued that the Servier award could not be disclosed due to Article 32(5) of the UNCITRAL Arbitration Rules (1976), which governed the Servier arbitration. As discussed in Section 1 above, Article 32(5) provides that awards 'may be made public only with the consent of both parties'. According to the STSO, Article 32(5) constituted a rule on disclosure (ie, mandating confidentiality) that differed from the rule under the FOI Act (ie, mandating publication). This conflict was resolved, for the STSO, by Article 1.2 of the FOI Act, which (as noted above) reads that ' $[\mathrm{t}]$ he provisions of the Act shall not breach the provisions of other acts defining different principles and the mode of access to the information being public information.' The effect of Article 1.2, according to the STSO, was that the confidentiality indicated by the UNCITRAL Arbitration Rules should prevail over the disclosure indicated by the FOI Act. ${ }^{87}$

In its judgment of 25 October 2012, the Regional Administrative Court in Warsaw ${ }^{88}$ first confirmed that arbitral awards rendered in investor-State arbitration against Poland constitute 'public information' within the meaning of the FOI Act. ${ }^{89}$ The court further ruled, contrary to the STSO's submissions, that the STSO was an authority bound by the provisions of the FOI Act.

More substantively, the court went on to reject the STSO's views on Article 1.2 of the FOI Act. In particular, the court found that neither Article 32(5) of the UNCITRAL Arbitration Rules nor Article 8.2 of the Poland-France BIT (the clause providing for UNCITRAL investor-State arbitration) could be understood as defining different 'principles' or 'modes of access' to information under Article 1.2 of the FOI Act. $^{90}$

As a result of the above judgment, the STSO then released a redacted version of the Servier award, purporting to comply with the court's ruling. ${ }^{91}$ However, this effort at compliance appeared minimal: the version of the award released by the STSO included only the first and the last pages of the award (in total consisting of 190 pages), with further redactions made even to those two pages. In justifying its refusal to release the full award, the STSO then introduced a new contention, based on the trade secrets of investors. ${ }^{92}$

85 The motion was filed by Krzysztof Izdebski from the Citizen Network - Watchdog Poland.

86 As described in the judgment of the Regional Administrative Court of Warsaw, II SAB/Wa 252/12, 25 October 2012.

87 As described in the judgment of the Regional Administrative Court of Warsaw, II SAB/Wa 252/12, 25 October 2012.

88 Wojewódzki Sąd Administracyjny w Warszawie.

89 Regional Administrative Court of Warsaw, II SAB/Wa 252/12, 25 October 2012.

90 Although the court did not clarify its reasoning on this point, it may have taken this view on the grounds that Article 32(5) of the UNCITRAL Arbitration Rules only prevents the tribunal from disclosing the award, and not the parties themselves, as suggested in Section 1.

91 Decision of 22 February 2013, on file with authors.

92 Ibid. 
After a further motion for reconsideration and upholding of the decision by the STSO, the applicant once again filed another complaint in the administrative courts, in relation to the newly-alleged ground of trade secrets.

In a judgment of 15 November 2013, the Regional Administrative Court in Warsaw reaffirmed that arbitral awards rendered in investor-State arbitration are "public information' within the meaning of the FOI Act, and that the STSO was bound by the provisions of the FOI Act. ${ }^{93}$ The court then requested the STSO to provide it with a translation of the English-language Servier award into Polish, in order to assess whether all the prerequisites necessary to deny access to public information based on trade secrets were met in the case. The STSO did not possess such a translation, and it did not present the translation to the court. As a result, the court held that the STSO's decision to refuse access to the award on the grounds that it contained trade secrets, while making this decision on the basis of an English text, was not justifiable under the applicable provisions of the Polish law. ${ }^{94}$ The court therefore annulled both decisions of the STSO. The STSO filed an appeal against this judgment, which remains pending at the time of preparing the present article.

\section{IV.3.2. The First Ministry of Health Proceedings}

A separate motion seeking access to the Servier award was addressed to the Ministry of Health, who was responsible for representing the State in the case. ${ }^{95}$ While deciding on the motion, the Ministry of Health approached the investor-claimants in the Servier case, asking them directly which parts of the award contained trade secrets. Apparently, in light of their response, in August 2012, the Ministry denied access to the award. It argued, among other points, that redacting the award in order to protect the investors' trade secrets would result in the creation of 'processed information', which in turn - according to Article 3 of the FOI Act - can be published only when 'it is particularly essential for the public interest'. ${ }^{96}$ According to the Ministry, the applicant had not proven the existence of such essential public interest. ${ }^{97}$

After an unsuccessful motion for reconsideration, the applicant again filed a complaint with the administrative court. In its judgment of 7 May 2013, ${ }^{98}$ the Regional Administrative Court in Warsaw agreed that the Servier award 'contains information which is not subject to disclosure because of protection of trade secrets'. However, in its view, redacting this commercial confidential information would not result in creating 'processed information' exempt from disclosure under Article 3 of the FOI Act. As a result, the Court found, the applicant could not be obliged to prove a 'particularly essential public interest' to justify the motion. Instead, the Court considered that the non-confidential parts of the award should be released, and that

93 Regional Administrative Court of Warsaw, II SA/Wa 909/13, 15 November 2013.

94 The court based its decision on the provisions of the Act of 7 October 1999 on the Polish language, Journal of Laws No 90 pos 999 as amended (Polish Language Act); and on the Act of 14 June 1960 Code of Administrative Procedure, Journal of Laws No 30 pos 168 as amended (Code of Administrative Procedure).

95 The motion was filed by Krzysztof Izdebski from the Citizen Network - Watchdog Poland.

96 Article 3 of the FOI Act: echoing the ECtHR's finding in the Társaság case, discussed in Section 2, that States have greater obligations to provide information when it is already collected and requires no further work or processing.

97 As described in the judgment of the Regional Administrative Court of Warsaw, II SA/Wa 2249/12, 7 May 2013.

98 Regional Administrative Court of Warsaw, II SA/Wa 2249/12, 7 May 2013. 
the mere fact that parts of the arbitral award contained information protected by law could not justify a total denial of access to the document.

Finally, the Court referred to the October 2012 judgment in the STSO proceedings (discussed above). ${ }^{99}$ The Court reaffirmed the view that Article 1.2 of the FOI Act did not operate to privilege the UNCITRAL Arbitration Rules and Poland-France BIT over the FOI Act itself.

Following this judgment, a complete, although partly-redacted, copy of the Servier $v$ Poland arbitral award was provided to the applicant.

\section{IV.3.3. The Second Ministry of Health Proceedings}

Meanwhile, another motion with respect to the Servier award, filed in parallel to the efforts described above, was also addressed to the Ministry of Health. ${ }^{100}$ In these proceedings, the Ministry of Health also denied access to the award, ${ }^{101}$ relying again on the existence of trade secrets in the award. In this case, however, the authority did not claim that redacting the award would result in creation of 'processed information'. Following a motion for reconsideration, the Ministry upheld its decision, ${ }^{102}$ while adding a view that the arbitral award should be treated as an 'integral part' and cannot be published 'in parts' without releasing trade secrets. ${ }^{103}$

On 20 August 2013, in response to the applicant's complaint to the administrative courts, the Regional Administrative Court in Warsaw issued a judgment in which it annulled both decisions of the Ministry of Health. ${ }^{104}$ As in the Servier case, the Court requested the Ministry to provide a copy of the arbitral award translated into Polish in order to verify whether denial on grounds of trade secrets was indeed justified. ${ }^{105}$ The Ministry of Health did not possess such a translation, and did not provide it to the Court. The Court therefore concluded that the whole administrative proceedings were inconsistent with the requirements of the domestic law. ${ }^{106}$

Although the Servier decision had already been released by this stage, as noted above in relation to the first set of proceedings against the Ministry, the Ministry of Health nevertheless filed an appeal. ${ }^{107}$ The Supreme Administrative Court, in its judgment of 5 September 2014, confirmed that arbitral awards issued in investor-State proceedings constitute 'public information' within the meaning of the FOI Act, and that the Ministry of Health is obliged to release such public information in accordance with the FOI Act. ${ }^{108}$ Further, it upheld the arguments of the Court of first instance as to the Ministry's obligation to base its decision on a Polish translation of the award. Importantly, the Supreme Administrative Court also observed that there were no legal grounds to require the applicant who filed the motion to bear the costs of this translation. However, in a recent, surprising move following the Supreme Administrative Court's judgment, the Ministry of Health appeared to ignore the

\footnotetext{
99 Regional Administrative Court of Warsaw, II SAB/Wa 252/12, 25 October 2012.

100 The motion was filed by Filip Balcerzak.

101 Decision of 7 December 2012, on file with authors.

102 Decision of 28 February 2013, on file with authors.

$103 \mathrm{Ibid}$. This approach was based, among others, on the fact that the investors opposed publication of the award.

104 Regional Administrative Court of Warsaw, II SA/Wa 838/13, 20 August 2013.

105 According to the Polish Language Act.

106 The Polish Language Act and the Code of Administrative Procedure.

107 Skarga kasacyjna.

108 Supreme Administrative Court, I OSK 2966/13, 5 September 2014.
} 
judgment, requesting the applicant to bear costs of the translation of the awards into Polish. ${ }^{109}$

\section{IV.4. Subsequent Attempts to Obtain Arbitral Awards through the FOI Act ${ }^{110}$}

\section{IV.4.1. Crespo v Poland}

Following the relative success encountered in the various Servier proceedings and the eventual release of a redacted version of the award, attention was turned to other stillunpublished investment treaty awards in cases involving Poland.

One such case is Crespo v Poland, a claim under the Poland-Spain BIT and the 1998 ICC Arbitration Rules. ${ }^{111}$ A motion to access the 2005 award in this case was filed with the Polish Ministry of Finance. ${ }^{112}$ The Ministry initially denied the request, ${ }^{113}$ and a motion for reconsideration was unsuccessful. ${ }^{114}$

Two main grounds, already familiar from the Servier claims, were relied on by the Ministry. First, the Ministry contended that Article 1.2 of the FOI Act would apply, because, although the Act itself might point towards disclosure, other relevant instruments that provided for 'confidentiality' would override the Act by virtue of Article 1.2. In particular, the Ministry cited Article 28 of the 1998 ICC Rules, which provided that 'additional copies' of an arbitral award 'shall be made available on request and at any time to the parties, but to no one else' ${ }^{115}$ The Ministry also drew the confidential nature of the arbitral award from Article 11 of the Poland-Spain BIT (which contained the State's consent to ICC arbitration). Second, the Ministry contended that the award contained trade secrets and fiscal secrets, and that redaction of the award to exclude this information would leave the document totally deprived of its content.

As with the Servier proceedings, these decisions from the Ministry of Finance were challenged before the Polish administrative courts. On 22 October 2014, the Regional Administrative Court in Warsaw annulled both decisions. ${ }^{116}$

On the Ministry's first contention, the Court held that Article 11 of the Poland-Spain $B I T$ regulates only the issue of dispute settlement between investors and States. In the view of the Court, this arbitration clause could not 'define different principles and the

109 Letter of 15 January 2015, on file with authors. The costs of translation are estimated at the level of PLN 7,166.16. Based on an average exchange rate published by the Polish National Bank from 27 February 2015, it amounts to approximately USD 1,937.85. At the time of publication, no further action has been taken in relation to this motion.

110 This section does not aim to describe in full all the attempts undertaken in order to obtain copies of the arbitral awards rendered in BIT proceedings against Poland. Other proceedings are pending, for example with respect to awards rendered in Cargill v Poland, UNCITRAL, Award, 1 March 2008; Mitch Nocula v Poland (no known citation); and TRACO Deutsche Travertinwerke GmbH v The Republic of Poland, UNCITRAL, Award, 5 September 2012.

111 International Chamber of Commerce (ICC), ICC Arbitration Rules (1998) (ICC Rules).

112 Julian Crespo Santamargarita, Juan Ricardo Crespo Santamargarita, Valencja sp z oo v Poland, ICC, Award, 22 September 2005. The motion was filed by Filip Balcerzak.

113 Decision of 19 February 2014, on file with authors.

114 Decision of 17 April 2014, on file with authors.

115 The Ministry also cited Article 6, ICC, Statutes of the International Court of Arbitration, 1 January 2012, and Article 1, ICC, Internal Rules of the International Court of Arbitration, then in force, to underpin a general principle of confidentiality in ICC arbitration.

116 Regional Administrative Court of Warsaw, II SA/Wa 1122/14, 22 October 2014. 
mode of access to the information being public information' within the meaning of Article 1.2 of the FOI Act. Furthermore, the Court considered that no other provision of the BIT contained any regulation of access to public information. As for the ICC Rules and the other instruments cited by the Ministry, the Court held that these similarly did not introduce 'different principles' on access to information. In any case, the Court added that these instruments were not of a statutory level; for the Court, only statutory provisions could create an exception to the applicability of the FOI Act under Article 1.2.117

On the Ministry's second contention, the Court decided that, even if parts of the arbitral award contained trade secrets and fiscal secrets, even a 'superficial lecture of the award' allowed it to conclude that the Ministry's decision to deny access to the entire award was not justifiable. ${ }^{118}$

\section{IV.4.2. Mercuria v Poland}

A further request for access to public information was directed to the Ministry of Economy, with respect to the awards rendered in Mercuria $v$ Poland, ${ }^{119}$ heard under the Energy Charter Treaty and the SCC Arbitration Rules. ${ }^{120}$

In deciding on this request, the Ministry of Economy consulted the investor in the underlying case, who strongly opposed making the awards public even in a redacted form. The Ministry then issued a decision denying access to the award. ${ }^{121}$ In this decision, it relied, inter alia, on the Article 1.2 exception in the FOI Act, as the Ministries of Health and Finance had also done. However, following a motion for reconsideration, the Ministry conceded that this exception did not apply. ${ }^{122}$

Despite its concession, the Ministry upheld its decision to deny access based on the confidentiality of the proceedings. It argued that arbitral proceedings and arbitral awards are confidential, according to Articles 27.3 and 46 of the SCC Arbitration Rules. ${ }^{123}$ It further added that granting access to the awards could give the investor grounds for compensation claims from the State, and would negatively impact relations between foreign investors and Poland. Last, the Ministry argued that it was not competent to assess which parts of the Mercuria award contained trade secrets, and thus that it must rely on the investor's indication that the awards in their totality should be treated as trade secrets.

Once again, the applicant filed a complaint to the administrative court. On 15 January 2015, the Regional Administrative Court in Warsaw issued a judgment, in which it annulled both decisions of the Ministry of Economy. ${ }^{124}$

117 Ibid.

118 The Ministry of Finance did not appeal, and the judgment became binding only shortly before finalising the present article for publication.

119 Mercuria Energy Group Limited v Republic of Poland, SCC, Decision on Jurisdiction, December 2009, and Final Award, 1 December 2011. The motion was filed by Filip Balcerzak.

120 Stockholm Chamber of Commerce (SCC), Arbitration Rules (2010) in force as of 1 January 2010 (SCC Arbitration Rules)

121 Decision of 22 May 2014, on file with authors.

122 Decision of 10 July 2014, on file with authors.

123 Article 27.3, SCC Arbitration Rules: 'Unless otherwise agreed by the parties, hearings will be in private.' Article 46, SCC Arbitration Rules: 'Unless otherwise agreed by the parties, the SCC Institute and the Arbitral Tribunal shall maintain the confidentiality of the arbitration and the award.'

124 Regional Administrative Court of Warsaw, II SA/Wa 1690/14, 15 January 2015. 
The Court affirmed that, even though the right to access to public information is guaranteed at the constitutional level in Poland, the right is not absolute, and can be limited - including, in particular, where a party's trade secrets might be publicly revealed. The Court then analysed the meaning of the term 'trade secrets' in the Polish law. It concluded that the mere will of the investor to keep information secret was not enough, by itself, to qualify it as a 'trade secret' protected by law. Another prerequisite must be met: the information has to constitute technical, technological, organisational or other information of economic value. Thus, the court held that the Ministry of Economy must assess whether the investor's own designation of information as a trade secret was objectively justifiable. For the Court, both formal and material prerequisites must be met in order to deny access to public information, with the burden of proof lying on the investor. ${ }^{25}$

In response to the Ministry's claims of the inherent confidentiality of arbitration, the Court offered some views on the nature of arbitration. The Court described arbitration as a mechanism of dispute settlement according to rules of procedure and substance agreed by the parties in their arbitration agreement, with the competence of the arbitral tribunal based on this agreement. The Court added that one main characteristic of arbitration was that, for the purposes of enforcement, states typically agree to treat arbitral awards as equivalent to judgments issued by State courts. Following the Court's reasoning, the crucial practical relevance of considering arbitral awards as equal to judgments of State courts is visible at the moment of enforcement proceedings. The Court then observed that it is well established in Polish law that judgments of State courts are 'public information' within the meaning of the FOI Act. It concluded that it was impossible to find that the nature of arbitration would limit the applicability of domestic law, particularly where the domestic law right in question was guaranteed at the constitutional level.

In addition, no provisions on access to public information were included in the Energy Charter Treaty, ${ }^{126}$ the instrument underlying the Mercuria dispute, and no conclusion to the contrary could emerge from any provisions of the SCC Rules, including Articles 27.3 or 46 . According to the Court, parties to arbitral proceedings could not agree on anything contrary to binding provisions of law, including the Polish FOI Act. In any case, similar to the findings in the Crespo proceedings (discussed above), the Court held that the SCC Arbitration Rules were not statutorylevel legal norms and were not universally binding. Last, as mentioned in Section 1 above, the Court also noted that the principle of confidentiality in Article 46 of the SCC Rules is directed towards the arbitral tribunal only and not the parties (including the State) themselves. In consequence, the parties themselves could decide on making the arbitral award public - and this decision could not be made in a manner contrary to binding provisions of law, such as the FOI Act. ${ }^{127}$

125 Ibid.

126 Energy Charter Treaty (1995) 2080 UNTS 95.

127 The Court's judgment in this case was not yet binding at the time of finalising this article for publication. 


\section{IV.5. Signs of a Positive Approach Amongst Polish Authorities Towards Transparency? David Minnotte v Poland, Nordzucker $v$ Poland and Saar Papier $v$ Poland}

Despite the difficulties in seeking release of information from Polish authorities described above, there are other, more positive examples of instances where authorities have released awards without the need for resort to the judiciary.

First, the 2005 award in Eureko $v$ Poland was released to the public, ${ }^{128}$ although it remains unknown whether it was released by any of the parties to the dispute on their own initiative, or under any other ground.

Second, contrary to its reluctance in publishing the award issued in Servier $v$ Poland, the Ministry of Health published copies of the awards in David Minnotte and Robert Lewis $v$ Poland $d^{129}$ on the authority's own initiative, together with a statement on the case. $^{130}$

The Ministry's decision to publish the Minnotte and Lewis award, while being so reluctant to grant access to the Servier award, is striking for its lack of consistency. It might be argued that the former case was conducted under the ICSID Additional Facility Rules, which generally introduces a higher level of transparency than applicable in the Servier case, which was conducted under UNCITRAL Rules. Alternatively, the reason may be more pragmatic: while Poland was ordered to pay around EUR 4 million in compensation in Servier, it prevailed entirely in Minnotte and Lewis, including receiving an order for the reimbursement of its costs. ${ }^{131}$

There are also examples of immediate positive reactions of the State authorities in response to motions to access public information. For instance, the STSO released to the applicant the award rendered in East Cement $v$ Poland ${ }^{132}$ without any need to file a motion for reconsideration or to present a claim to the administrative court. Similarly, following a request under the FOI Act, the Ministry of State Treasury granted access to arbitral awards rendered in Nordzucker $v$ Poland and Saar Papier v Poland. ${ }^{133}$ Again, in these cases, there was no need to file a motion for reconsideration or to present a claim to the administrative court. The Ministry of Infrastructure and Development has also released upon request a redacted version of the notice of dispute served on Poland by an Austrian investor (whose identity was anonymised). ${ }^{134}$

128 Eureko BV v Republic of Poland, Partial Award, 19 August 2005, together with the dissenting opinion.

129 David Minnotte and Robert Lewis $v$ Republic of Poland, ICSID Additional Facility, Case No ARB (AF)/10/1, Award, 16 May 2014, Decision on the Request for Interpretation of the Award, 22 October 2014.

130 Ministry of Health, 'Komunikat' at <www.mz.gov.pl/dla-mediow/informacje-prasowe/komunikatw-sprawie-david-minnotte-i-robert-lewis-przeciwko-rzeczypospolitej-polskiej-sprawa-icsid-nrarbaf101-oraz-sprawa-vincent-j.-ryan-i-inni-przeciwko-rzeczypospolitej-polskiej-sprawa-icsd3-nrarbaf113> (accessed 20 May 2014).

${ }^{131}$ In the amount of USD 1,217,741.29. See, David Minnotte and Robert Lewis $v$ Republic of Poland, CSID Case No ARB (AF)/10/1, Award, 16 May 2014, para 217.

132 East Cement for Investment Company v Poland, ICC, Partial Award, 26 August 2011. The motion was filed by Filip Balcerzak.

133 Nordzucker v Poland, UNCITRAL, Partial Award (Jurisdiction), 10 December 2008, Second Partial Award (Merits), 28 January 2009, Third Partial and Final Award (Damages and Costs), 23 November 2009; Saar Papier Vertriebs GmbH v Poland, UNCITRAL, Interim Award (Jurisdiction), 17 August 1994, with dissenting opinion, and Final Award, 16 October 1995, with dissenting opinion. The motions were filed by Filip Balcerzak.

134 Letter of 20 March 2014, on file with authors. The motion was filed by Filip Balcerzak. 


\section{Conclusions}

Investment disputes concern governmental conduct and implicate public money. The public should, therefore, have the opportunity to become familiar with arbitral awards rendered in investor-State arbitration. Some awards have been released under obligations of disclosure in investment treaties or arbitral rules, as Section 1 demonstrated. Certainly, in this respect, one can observe a trend in favour of transparency of investment arbitration. However, although many awards find their way into the public domain, numerous other awards remain hidden from the public.

The fact that some awards still remain hidden sits in some tension with the growing recognition of the right to access public information, a right guaranteed in the international system of human rights as well as in the Inter-American and European regional systems. As discussed in Section 2, the relevance of this right of access to public information cannot be underestimated. Indeed, in a 2013 report, the then Special Rapporteur on the Promotion and Protection of the Right to Freedom of Expression, Frank La Rue, observed that 'core requirements for democratic governance, such as transparency, the accountability of public authorities, or the promotion of participatory decision-making processes, are practically unattainable without adequate access to information. ${ }^{135}$ The Special Rapporteur gave the objective of combating corruption as a prime example of a goal calling for 'the adoption of procedures and regulations that allow members of the public to obtain information on the organisation, functioning and decision-making processes of its public administration'. ${ }^{136}$

A concrete example of the public benefits that flow from disclosure in investment treaty cases is provided by the ICSID case World Duty Free $v$ Kenya. ${ }^{137}$ This case involved allegations that Kenya had expropriated the investor's duty free business at Nairobi and Mombasa airports. ${ }^{138}$ The case collapsed, however, when evidence tendered in the proceedings demonstrated that the former President of Kenya, Daniel arap Moi, had accepted a bribe in return for securing the investor's project in the host State. Disclosure of this information via the eventual publication of the ICSID award, was crucial in supporting the Kenyan people's ability to hold public officials to account. Although no freedom of information claim was involved in gaining access to the ICSID award, the case demonstrates the potential for access to information procedures to bring a direct and tangible benefit to efforts aimed at improving governance. ${ }^{139}$

135 United Nations General Assembly, Report of the Special Rapporteur on the Promotion and Protection of the Right to Freedom of Opinion and Expression, UN Doc A/68/362, 4 September 2013, at <daccess-ddsny.un.org/doc/UNDOC/GEN/N13/464/76/PDF/N1346476.pdf?OpenElement> (accessed 3 May 2015), para 3. Mr La Rue's mandate as Special Rapporteur expired in July 2014, with the post currently being held by David Kaye.

136 Ibid.

137 World Duty Free Company Limited v Republic of Kenya, ICSID Case No ARB/00/7, Award, 4 October 2006 (World Duty Free).

138 According to the investor in the case, Kenya had made it an unwitting participant in a large-scale electoral financing fraud, later deporting the investor's director, and liquidating and seizing control of the company to destroy evidence of the fraud: World Duty Free, para 70.

139 It should also be noted that the World Duty Free case was not an investment treaty claim, but was brought to ICSID under an arbitration clause in the claimant's investment contract. However, this does not diminish the importance of the revelations of the case in terms of access to information. 
Whether or not this potential can be fully realised, however, remains somewhat unclear following the experience in the Polish case-study described in Section 3. It is true that, in all the cases which were heard by the administrative courts in Poland, the courts annulled the decisions to deny access to public information. Thus, the approach of Polish judiciary is consistent with the importance of the right to access public information, as guaranteed in the Constitution of Poland. It is also in line with the human rights dimension of this right. Even though no express reference to human rights was made by the administrative courts in any of the claims examined in Section 3 , the courts' reasoning conforms with the judgments issued by the European Court of Human Rights in Társaság a Szabadságjogokért v Hungary, Österreichische Vereinigung zur Erhaltung, Stärkung und Schaffung v Austria and Youth Initiative for Human Rights v Serbia.

The attitude of the Polish executive, meanwhile, tells a slightly different story, demonstrating reluctance to comply with its commitments under the FOI Act. Such an approach is not in conformity with Poland's human rights obligations, which are binding on all branches of the State. ${ }^{140}$ Furthermore, it also highlights the fact that the scope of competence of the administrative courts is limited. Although the courts can quash the administrative decisions of Polish authorities, these authorities have, in some instances, simply continued to render decisions denying access to public information on different grounds, therefore breaching their obligation to respect human rights. ${ }^{141}$

This was seen, for example, in the approach of the STSO (which granted access to two pages out of a 190-page arbitral award) and the Ministry of Health (which required the applicant to pay translation costs without legal basis) with respect to the Servier $v$ Poland, described in Section 3. Such behaviour forces applicants to file continual complaints to the administrative courts, amounting to a cat-and-mouse game between the individual and the public authorities. This can significantly delay attempts to obtain arbitral awards, potentially leading applicants to surrender their efforts in the face of State power.

In addition, the arguments invoked by the authorities varied, at least to a certain degree, in every proceeding in which the competent authorities denied access to an award. Almost all of these arguments were ultimately rejected by the administrative courts, with the judiciary agreeing only with the limitation of access by way of redaction to protect investors' trade secrets.

At its most pessimistic, then, Section 3 demonstrates that use of domestic FOI laws requires expert knowledge of the target State's political environment, court procedures and legal system. The Polish experience suggests that FOI claims can be expensive, difficult, complicated and slow.

Despite all this, other recent developments are promising. As Section 3 has shown, the use of domestic access to information laws can, in the right circumstances, be a useful tool in gaining access to long-hidden investment treaty awards, relying on issues of strong public importance. Release of the Servier $v$ Poland award may therefore be the first step in a change of attitude amongst Polish authorities on the larger question of transparency in investment treaty arbitration. Such a shift would be entirely in line

140 GC34, para 7.

141 To avoid such behaviour, the FOI Act even provides for criminal liability. Article 23, the FOI Act: reads as follows: 'Whoever, contrary to the obligation weighing on him, shall not make the public information available, is subject to fine, penalty of restricted liberty or penalty of deprivation of liberty for up to one year.' However, the authors are not aware of any criminal procedure, not mentioning any judgment, based on this provision. 
with Poland's (and other countries) human rights obligations outlined in Section 2, and with developments at the United Nations outlined in Section 1. In fact, with respect to some awards, the Polish executive has indeed acted more transparently, for instance by voluntarily publishing the award in David Minnotte and Robert Lewis $v$ Poland, and by granting access to other awards upon request under the FOI Act without need for resort to the administrative courts. Thus, efforts under the domestic FOI laws aimed at publishing arbitral awards rendered in arbitral proceedings based on investment treaties have the potential to drive a desirable shift of States' authorities towards transparency in the field. 